\title{
WAYS TO IMPROVE PROCESS OF WET GRANULATION OF FERMENTED POULTRY LITTER SOLID FRACTION
}

\author{
Viktor Marchenko, Dmitry Sidelnikov \\ Stavropol State Agrarian University, Russia \\ marchenko59@mail,dimasud@yandex.ru
}

\begin{abstract}
The carried-out analysis of designs of granulators for the process of damp pressing showed that this method is implemented by means of screw granulators better. At the same time effective objectives are achieved by production of the end product - granules, their quantitative and qualitative indexes. Preliminary search experiments on pressing of firm fraction of the fermented bird dung in the screwgranulator, which is most meeting the requirements of obtaining a certain quantity of qualitative granules, are made. The unstable movement of the pressed material in matrix dies was as a result revealed. It does not allow to reach the required capacity of the screw granulator and to receive granules with quality characteristics.For realization of an effective objective - obtaining necessary quantity of qualitative granules from firm fraction of the fermented bird dung the constructive and technology scheme of the screw granulator is proved. For this purpose innovations are entered into a design of the screw granulator: zone of plasticization and bladed knife. The zone of plasticization is located between the screw and the matrix in the screw granulator and the bladed knife in the plasticization zone before the matrix.Researches of the process of damp granulation were conducted by means of a multiplefactor planning method of an experiment. During the research of the process of damp granulation of FF FBD in the screw granulator we studied the following factors: frequency of rotation of the screw of the granulator (17$\left.27 \mathrm{rad} \cdot \mathrm{s}^{-1}\right)$, humidity of the pressed material (34-40\%) and the number of blades of the knife $(0-4 \mathrm{pcs})$, influencing the productivity and specific expenses of energy. After processing of the results of the experiment performance (in the range of $240-265 \mathrm{~kg} \cdot \mathrm{h}^{-1}$ ) specific power costs were received (in the range of 17.1-24, $\left.317 \mathrm{~kW} \cdot \mathrm{h} \cdot \mathrm{t}^{-1}\right)$. The greatest influence both on the performance and specific power costs has the factor of the number of blades of the knife, the smallest - the frequency of rotation of the screw of the granulator. With increase in the number of blades of the knife, also the performance increases.
\end{abstract}

Keywords: wet granulation; screw granulator; granules; bird droppings; blades of the knife.

\section{Introduction}

The perspective direction of development of utilization of bird dung is creation of low-waste or completely wasteless resource-saving production [1]. The example of a similar technology is the resource-saving technology of utilization of the bird dung developed by the staff of the Machines and Technologies of Agrarian and Industrial Complex Department of the Stavropol State Agricultural University [2]. Biological decomposition of organic matter of bird dung in the conditions of anaerobic fermentation is fundamental of the technology. Not resolved issue in the technology line is the production phase of the granulated organic fertilizers (GOF), which will allow to use as much as possible nutritious and energy potential of bird dung. The granulated organic fertilizers have a demand from producers of crop products now.

The analysis of the equipment for granulation allowed us to make the choice for screw granulators, as this equipment guarantees receiving the product (granules) with the set properties [3]. However, during the operation of screw granulators the shortcomings, which improvement will promote improvement of technology process of wet granulation, were revealed. So, basic researches showed that the firm fraction of fermented bird dung (FF FBD) in the screw granulator is squeezed out unevenly longwise to the matrix that is expressed in receiving low-quality granules, and on matrix clear area - in the course of granulation there is swamping of flow section of die holes fibrous parts of FF FBD [4; 5].Basic reasons of the uneven exit of material, in our opinion, is the following: the irregularity of the flow of FF FBD happens because of pressure pulsations in the screw granulator before the matrix, at the same time pressure in the pre-matrix camera is $6.85 \mathrm{MPa}$ [6]; in the course of granulation on partitions of die holes of the matrix fibrous parts of FF FBD stick that considerably reduces the diameter of the die holes.

For elimination of shortcomings we offer to equip the granulator with the plug for arrangement of the plastication zone in it and the bladed knife for cleaning of the internal surface of the matrix of fibrous parts of FF FBD and additional pushing through of the pressed material in the matrix die holes.

Technique of researches. For the research of the process of wet granulation we mounted an experimental installation (Figure 1). It was equipped with the combined matrix, two-piece: steel - for 
formation of granules and fluoroplastic - for the stress relief, arising after pressing, the bladed knife for cleaning of partitions of the matrix of fibrous parts with FF FBD and a zone of the plastication serving for stabilization of supply of the pressed material in the matrix die holes.

The purpose of the study was to identify the regularity of the influence of the design and technological parameters of the wet granulation process in a screw granulator on the productivity and specific energy costs.

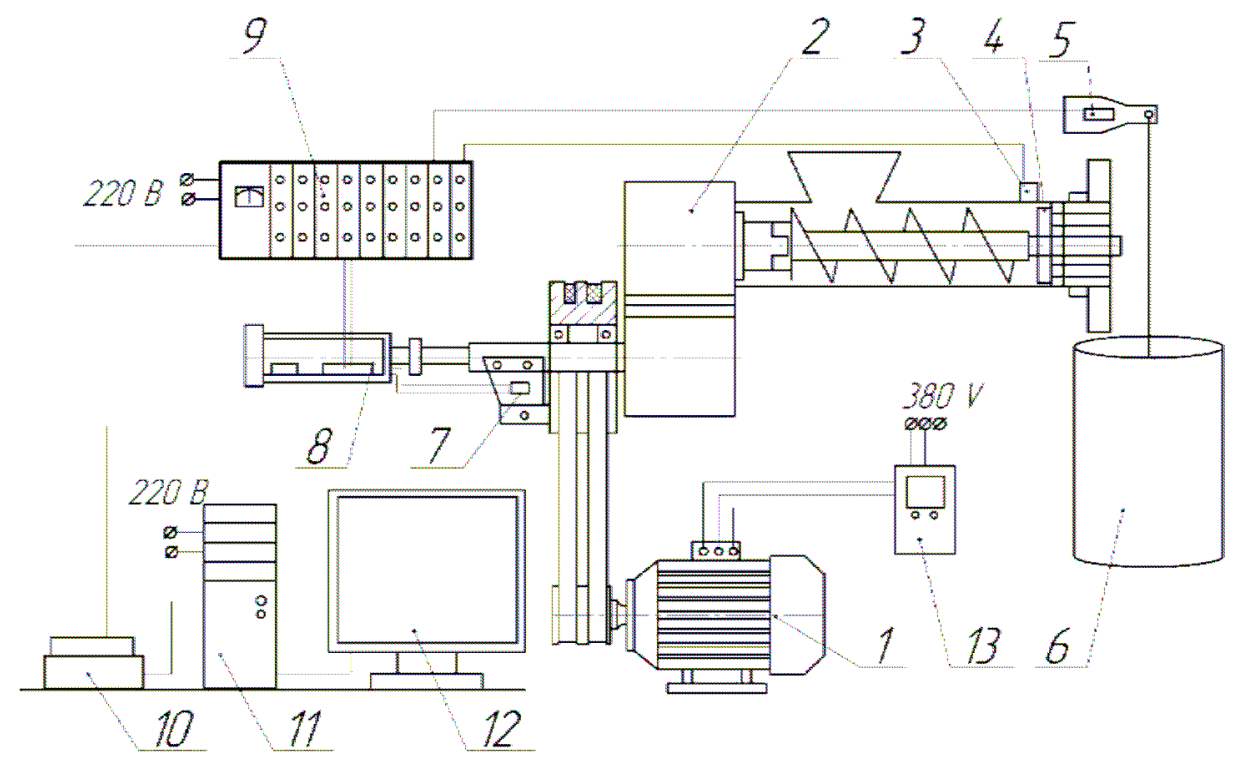

Fig. 1.Scheme of experimental installation for research of the process of wet granulation of $\mathrm{FF}$

FBD: 1 - electric motor; 2 - reducer; 3 - pressure sensor; 4 - forcing knife blades; 5 - strain gage; 6 - capacity for granules; 7 - strain gage for definition of the torsional moment; 8 - mercury amalgamated slip ring, tacho generator; 9 - amplifier 8ANCh-23; 10 - Sigma USB ATsPTsAP module; 11 - system unit of the computer with the ZETLab program; 12 - monitor; 13 - VFD-E series frequency converter Delta Electronics

\section{Materials and methods}

In the course of the research of the process of wet granulation of FF FBD inthe screw granulator we studied the following factors: rotating speed of the screw of the granulator, humidity of the pressed material and the number of blades of the knife. The last factor most influences productivity and, the more often there will be cleaning of the matrix of the sticking fibrous particles on matrix partitions, the more qualitatively there will be the process of wet granulation. For this purpose we made two bladed knives with two and four forcing blades (Figure 2).

a)

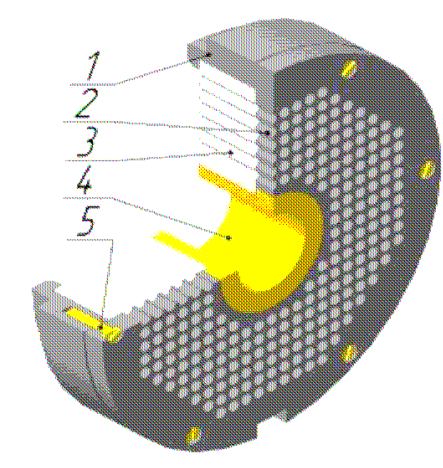

b)

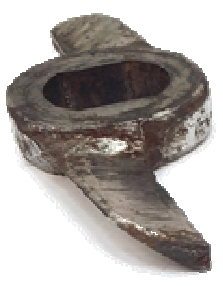

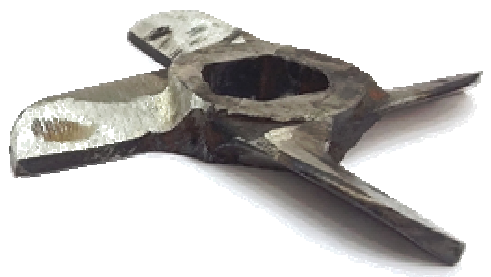

Fig. 2. Working nodes and parts of the screw granulator: $a$ - matrix combined; $b$ - appearance of blades of the knife; 1 - body; 2 - steel part (pressing); 3 - fluoroplastic part (relaxation); 4 - plug; 5 - fixing bolts

The results of the choice of major factors, intervals of their variation and levels for three-factorial experiment are shown in Table 1. 
Levels and intervals of variation of the studied factors

\begin{tabular}{|c|c|c|c|}
\hline Indicator & $\begin{array}{c}\text { Rotating speed of the } \\
\text { screw of the granulator, } \\
\mathbf{r a d}^{-\mathbf{1}} \mathbf{X 1}\end{array}$ & $\begin{array}{c}\text { Number of blades of } \\
\mathbf{a} \text { knife, pieces X2 }\end{array}$ & $\begin{array}{c}\text { Humidity of FF } \\
\text { FBD, \% X3 }\end{array}$ \\
\hline Naturaldesignation & $\boldsymbol{n}$ & $\boldsymbol{b}$ & $\boldsymbol{W}$ \\
\hline Toplevel (+1) & 27 & 4 & 46 \\
\hline Groundlevel (0) & 22 & 2 & 40 \\
\hline Lowerlevel (-1) & 17 & 0 & 6 \\
\hline $\begin{array}{c}\text { Interval of variation of } \\
\text { factors }\end{array}$ & 5 & 2 & 6 \\
\hline
\end{tabular}

For definition of operating modes of the screw granulator the technique of full-factor planning was used. Not a composition plan of the second order of Boksa-Benkin for three factors is adopted. Using methods of mathematical statistics for processing of the experimental data the mathematical models of the process of wet granulation describing dependences of productivity of $Y_{Q}(1)$ and specific expenses of energy $Y_{\text {Nud }}(2)$ from rotating speed of the screw, number of blades of the knife and humidity of FF FBDare received:

$$
\begin{aligned}
& Y_{Q}=259.77+6.21 X_{1}+60.37 X_{2}+5.38 X_{3}- \\
& -2.7 X_{1} X_{3}+4.65 X_{2} X_{3}+1.44 X_{1}^{2}-43.79 X_{2}^{2}-1.93 X_{3}^{2} \\
& Y_{\text {Nud }}=17.256+0.639 X_{1}-1.379 X_{2}-0.755 X_{3}- \\
& -0.092 X_{1} X_{3}+0.163 X_{2} X_{3}-3.085 X_{1}^{2}-0.692 X_{2}^{2}-4.34 X_{3}^{2}
\end{aligned}
$$

\section{Results and discussion}

Using the received mathematical models which geometrical interpretation is response surfaces, we carried out the analysis of the equations and curves (isolines) of the equal response from which follows:

1. Of the three controlled factors in the study limits on the parameter optimization performance of the granulator $\left(Y_{Q}\right)$ the largest impact factor is the number of blades and knife (X2) shown in equation (1) and the lowest humidity of FF FBD (X3).

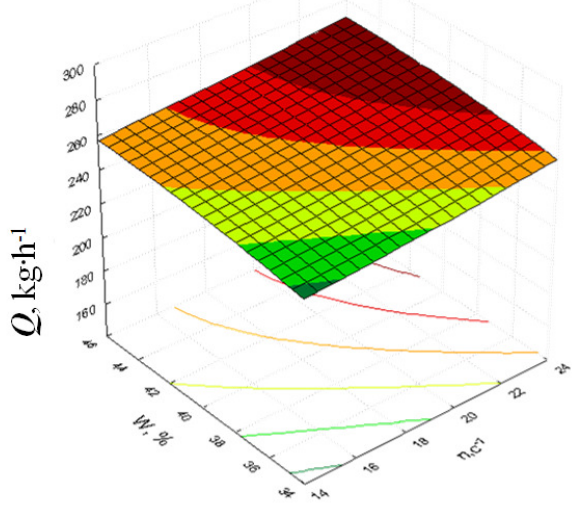

a) surface of the response of capacity of the screw granulator, $Q, \mathrm{~kg} \cdot \mathrm{h}^{-1}$

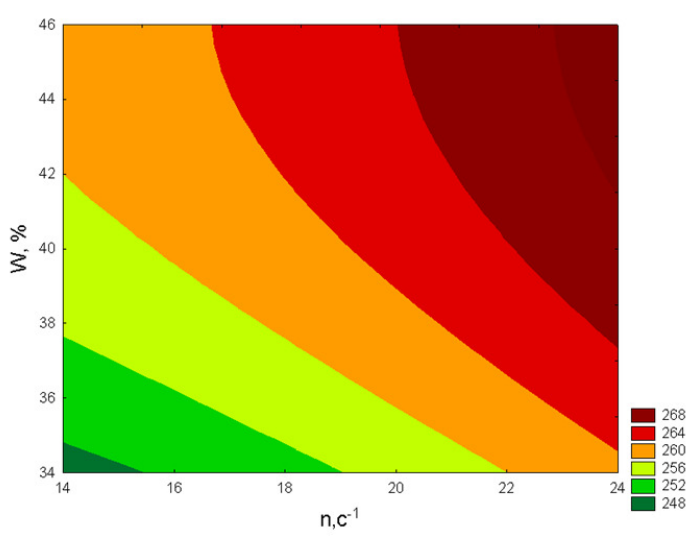

b) isolines of the response of productivityof thescrew granulator, $Q, \mathrm{~kg} \cdot \mathrm{h}^{-1}$

Fig. 3. Surface of the response and its isoline of productivity of $Q, \mathrm{~kg}^{-1} \mathrm{~h}^{-1}$ of the screw granulator at the constant number of blades $b=2$ pieces

The degree of influence of a combination of factors is shown in Figure 4, while it can be seen that the combination of them at the upper levels significantly increases the productivity of the granulator compared to the combination at other levels, but an increase in the humidity of FF FBD over $42 \%$ is technologically impossible, since free moisture begins to be squeezed out of the pressed material under pressure. 
2. The optimization parameter specific energy consumption $\left(Y_{N u d}\right)$ of the three regulated factors within the study limits is most influenced by the number of blades of the knife $b$ (X2), and the smallest - the rotation speed of the granulator screw $n$ (X1). The degree of influence of a combination of factors is shown in Figure 4.

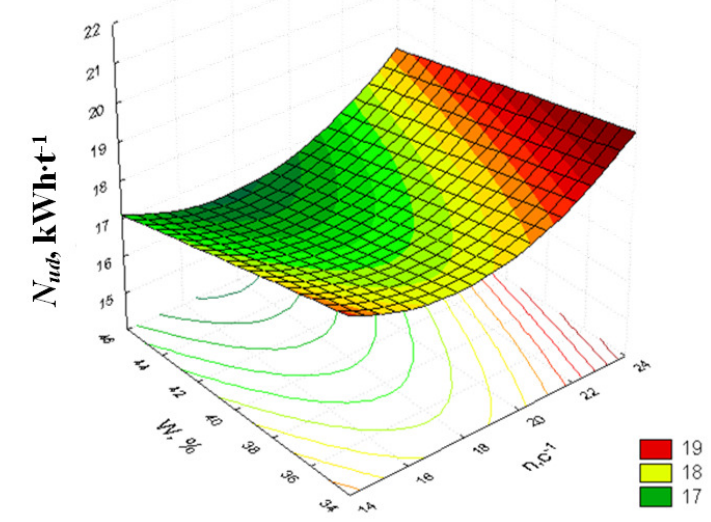

a) surface of the response of power density of the screw granulator $N_{u d} \mathrm{~kW} \cdot \mathrm{h} \cdot \mathrm{t}^{-1}$

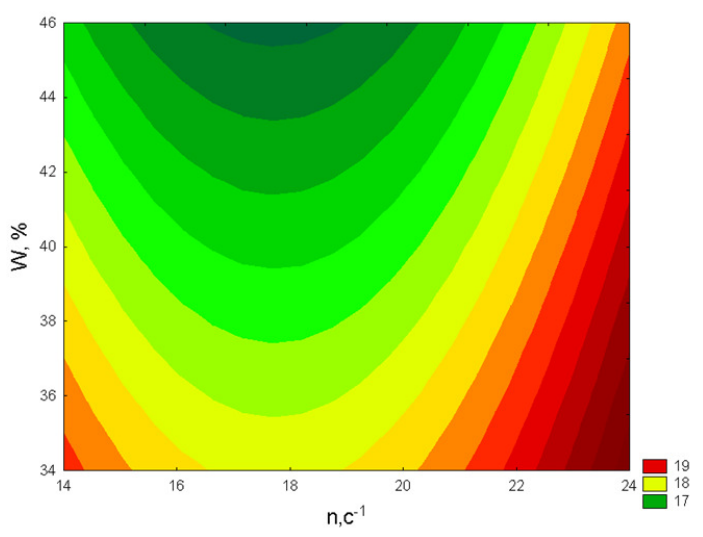

b) isolines of the response of power densityof thescrew granulator $N_{u d}, \mathrm{~kW} \cdot \mathrm{h} \cdot \mathrm{t}^{-1}$

Fig. 4. Surface of the response and its isoline of power densityof the screw granulator with the bladed knife $N_{u d}$ at the constant number of blades $b=2$ pieces

The regression equations of productivity $Q$ and power density $N_{u d}$ from the number of the forcing $b$ knife blades at humidity of FF FBD $\boldsymbol{W}=40 \%$ and rotating speeds of the $n=19 \mathrm{rad} \cdot \mathrm{s}^{-1}$ are given below:

$$
\begin{gathered}
Q=-6.5 b^{2}+38.5 b+208, \\
N_{u d}=5.11 b^{2}-22.48 b+41.62 .
\end{gathered}
$$

The obtained experimental data are adequate theoretically by Pearson's criterion that is presented in Figure 5.

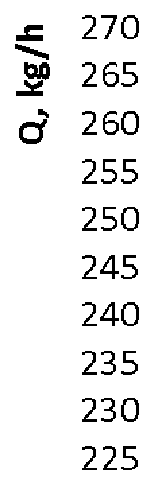
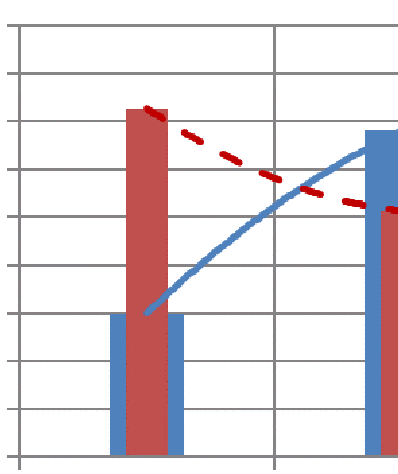

0

2

$$
\text { - of productivity of } Q, \mathrm{~kg} \cdot \mathrm{h}^{-1}
$$

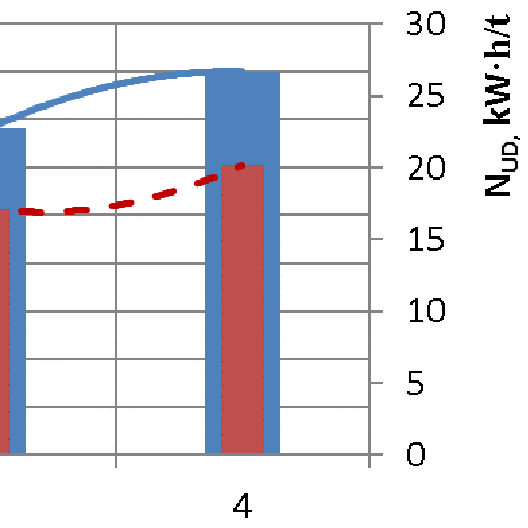

b, pieces

Fig. 5. Dependence of productivity $Q$ and power density $N_{U D}$ on the number of forcing $b$ knife blades at humidity of FF FBDW $=40 \%$ and rotating speeds of $n=19 \mathrm{rad} \cdot \mathrm{s}^{-1}$

\section{Conclusions}

The provided data show that the contrary flexure point comes at the number of the forcing knife blades equal 2. This number of the forcing blades is optimum as allows to receive granules of organic fertilizer from FF FBD with necessary qualitative physicomechanical characteristics at minimum power expenses. At the same time, the main performance indicators of the granulator were: productivity $N=257-264 \mathrm{~kg} \cdot \mathrm{h}^{-1}$, specific energy costs $P U D=16.5-17.3 \mathrm{~kW} \cdot \mathrm{h} \cdot \mathrm{t}^{-1}$ and the rotation 
speed of the screw $n=19.23 \mathrm{rad} \cdot \mathrm{s}^{-1}$. Physical and mechanical characteristics of granules: strength not less than $2.5 \mathrm{MPa}$ and crumblability not more than $1.5 \%$.

\section{References}

[1] Марченко В.И. Интенсификация анаэробного сбраживания птичьего помета (Intensification of anaerobic digestion of bird droppings) Tekhnika v selskomhozyajstve. 2011. N 6. pp. 27-29 (In Russian).

[2] Марченко В.И., Алексеенко В.А., Сидельников Д.А., Сляднев Д.Н. Ресурсосберегающая технология переработки отходов птицеводства (Resource-saving poultry waste processing technology) Mekhanizaciya I ehlektrifikaciya sel'skogo hozyajstva. 2010. N 1. pp. 8-10 (In Russian).

[3] Фролов, К.В. Машиностроение. Энциклопедия. Машины и оборудование пищевой и перерабатывающей промышленности (Mechanical engineering. Encyclopedia. Machines and equipment for food and processing industry) Machihina. - Moscow: Mashinostroenie, 2003. 736 p. (In Russian).

[4] Сидельников Д.А., Герасимов Е.В., Белый Ю.В. Гранулятор для прессования птичьего помета (Poultry Manure Press Granulator) $\cdot \mathrm{s}^{-1} \mathrm{el}$ 'skijmekhanizator. 2015. N 1. pp. 28-29. (In Russian).

[5] Марченко В.И., Сидельников Д.А., Панасенко А.В. Исследование влияния структурномеханических свойств твердой фракции сброженного птичьего помета на процесс влажного гранулирования (Investigation of the influence of structural and mechanical properties of the solid fraction of fermented bird droppings on the wet granulation process) Politematicheskij setevoj ehlektronnyj nauchny jzhurnal Kubanskogo gosudarstvennogo agrarnogo universiteta. 2016. - N 124. - pp. 1230-1243. (In Russian).

[6] Гребенник, Д.В. Гранулирование сброженного птичьего помета на шнековом прессесосборной матрицей (Granulation of fermented bird droppings on a screw press assembly matrix): dis. kand. tekhn. nauk/D.V. Grebennik. - Stavropol, 2001. - 200 p. (In Russian). 